\title{
The trophic status of Bidighinzu Reservoir (Sardinia) before and after the diversion of waste waters
}

\author{
Antonella LUGLIÈ*, Yelda AKTAN ${ }^{1)}$, Paola CASIDDU and Nicola SECHI \\ Department of Botany and Plant Ecology, University of Sassari, Via Muroni 25 - 07100 Sassari, Italy \\ ${ }^{1)}$ Faculty of Aquatic Products, University of Istanbul, Ordu cad No: 200 Lalely - 34470 Istanbul, Turkey \\ *e-mail corresponding author: luglie@ssmain.uniss.it
}

\begin{abstract}
The purpose of this paper was to assess the effect of the diversion of wastewater on the trophic status of Lake Bidighinzu, a hypertrophic man-made lake in Northern Sardinia, used as a drinking water reservoir. There have been problems with potabilization since the early years of the diversion operation, particularly in the summer-autumn period. Data available (August 1978, February 1979 and March 1985) before the reservoir (1987) were compared with those collected during a study carried out in the annual cycle immediately after (1988-1989) and after some years (1994 and 1996-1997). The study examined the dynamics of temperature, main nutrients (total phosphorus, nitrate and ammonia), chlorophyll-a and phytoplanktonic biomass. No particular variation in the water nutrient availability emerged from the comparison between these two situations - especially for total phosphorus, whose annual mean concentrations were similar in the two annual cycles (386 $\mathrm{mg} \mathrm{P} \mathrm{m}^{-3}$ in 1988-1989 and $305 \mathrm{mg} \mathrm{P} \mathrm{m}^{-3}$ in 1996-1997). Chlorophyll-a and biomass were high during each period of study (annual mean values were $17 \mathrm{mg} \mathrm{m}^{-3}$ and $3.7 \mathrm{mg} \mathrm{l}^{-1}$ in $1988-1989$ and $11 \mathrm{mg} \mathrm{m}^{-3}$ and $4.6 \mathrm{mg} \mathrm{l}^{-1}$ in 1996-1997). However, peaks were never higher than values recorded in August 1978 (112 $\mathrm{mg} \mathrm{m}^{-3}$ and $\left.133 \mathrm{mg} \mathrm{l}^{-1}\right)$ due to an extraordinary bloom of Ceratium hirundinella (O.F. Müller). Species composition of phytoplankton was typical of highly trophic conditions and was frequently characterised by the presence of Cyanophyceae and Bacillariophyceae. Results demonstrated that, ten years after construction of the by-pass, the lake had shown no improvement in its trophic status. This might depend on many factors, among which the most likely might be the non-use or partial use of the diversion system, which allows the sewage to continue to flow into the lake and keep its trophic status almost unchanged.
\end{abstract}

Key words: eutrophication, man-made lakes, aeration, diversion channel

\section{INTRODUCTION}

Lake Bidighinzu is a man-made lake in Northern Sardinia (Fig. 1, Tab. 1), used as a reservoir for drinking water. Problems of potabilization have arisen since the early years of the reservoir's use, particularly in summer-autumn, because of hypolimnic deoxygenation and the excessive presence of algae in the epilimnion. This was why an aeration system was installed in the area around the water intake tower (Messina 1966; Alamanni et al. 1968; Alamanni et al. 1971).

In 1978, Sechi \& Cossu (1979) determined the hypertrophic status of the lake on the basis of two samplings performed during the periods of circulation and thermal stratification. In 1986, Sechi confirmed this status (Sechi 1986, 1989) and assessed a theoretical load using Provini et al. (1979) conversion coefficients; this load was about $6.3 \mathrm{t} \mathrm{P} \mathrm{y}^{-1}$ against an admissible one of about $0.6 \mathrm{t} \mathrm{P} \mathrm{y}^{-1}$, calculated with the Vollenweider formula (O.E.C.D. 1980). In 1987, a by-pass was built to divert downstream of the dam the urban and industrial wastes of Thiesi, which were regarded as the main cause of the eutrophic condition of the reservoir (Sechi 1986; Marchetti et al. 1992). In 1988-1989, a limnological study was carried out with the main object of verifying the effects of this diversion. Values reported in Lugliè \& Sechi (1993) revealed no improvement in the trophic level, so that it was supposed that the diversion was too recent for any results to be recorded. In 1994 and 19961997 further studies were carried out. The results of these studies are reported in this paper and compared with the previous ones to show the effects of the diversion.

Tab. 1. Main characteristics of Lake Bidighinzu.

\begin{tabular}{lcc}
\hline Height at maximum storage & $\mathrm{m}$ a.s.l. & 334 \\
Maximum nominal volume & $\mathrm{m}^{3} 10^{6}$ & 11 \\
Maximum nominal area & $\mathrm{m}^{2} 10^{6}$ & 1.5 \\
Mean depth & $\mathrm{m}$ & 7.3 \\
Maximum depth & $\mathrm{m}$ & 30 \\
Building year & & 1958 \\
Catchment basin area & $\mathrm{km}^{2}$ & 52 \\
\hline
\end{tabular}

\section{METHODS}

The 1994 values referred to season samplings (March, June, September and December), whereas samples were collected almost monthly to study the annual cycle (December 1996 - November 1997); all the samples were taken from one station located about $500 \mathrm{~m}$ from the dam. Samples were taken with a Niskin bottle at depths of $0 \mathrm{~m}, 1 \mathrm{~m}, 2.5 \mathrm{~m}, 5 \mathrm{~m}, 7.5 \mathrm{~m}, 10 \mathrm{~m}, 15 \mathrm{~m}$ 


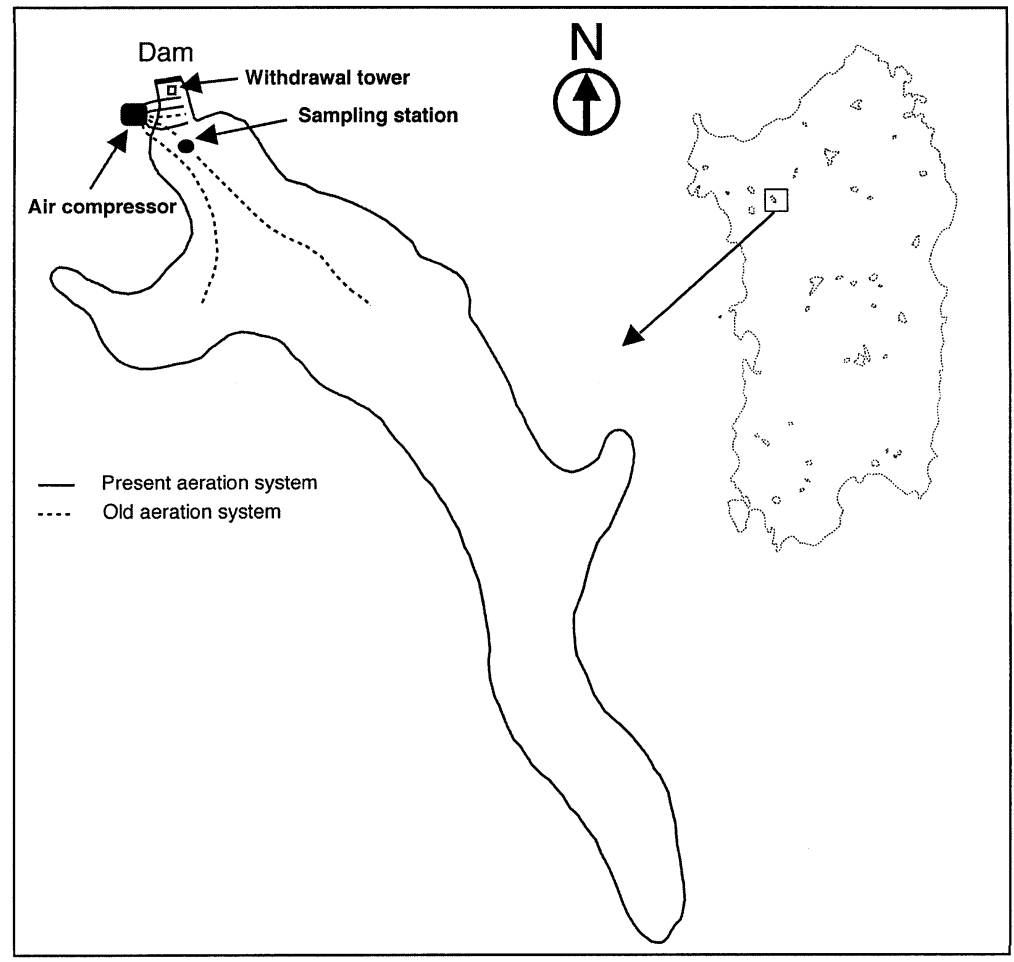

Fig. 1. Lake Bidighinzu showing the site of the sampling and its position in Sardinia together with all the other reservoirs.

and $20 \mathrm{~m}$. Of the parameters measured, trends of temperature, dissolved oxygen, ammonium nitrogen (Fresenius 1988), nitrate nitrogen, total phosphorus (according to Strickland \& Parsons 1968), chlorophyll-a (Goltermann et al. 1978), and total phytoplankton biomass (Findenegg 1974) are reported in this paper. Studies on phytoplankton were carried out to a depth of $10 \mathrm{~m}$.

\section{RESULTS}

Monthly averages along the vertical profile of parameters from 1978 onwards are reported in table 2; the oxygenation status of the hypolimnion in connection with single samplings is also reported. Annual mean values measured on the water column in accordance with monthly data collected in 1988-1989 and 19961997 and with the only four seasonal data recorded in 1994 are reported in table 3.

Temperature values were the same in the same months of different years (Tab. 2); the dynamics of temperature was typically seasonal (Fig. 2), with intense heating of the water from spring to summer and progressive cooling from autumn to winter. The lake became more or less clearly stratified, in relation to the use of the water aeration system during the first period; in contrast, full circulation occurred in winter.

Generally, nitrate nitrogen was higher than ammonium nitrogen in late winter and early spring (Tab. 2), whereas ammonium nitrogen was higher than nitrate nitrogen (Fig. 2) during stratification, especially in autumn, due to a marked hypolimnic deoxygenation. In
1996-1997, the annual averages of these two compounds showed no variation compared to those recorded in 1987-1988, except for a slight increase of nitrate (Tab. 3). On the other hand, in 1994 the annual averages showed a slight decrease in inorganic nitrogen (due to a drop in ammonium nitrogen) (Tab. 3). Concentrations of nitrate nitrogen found in August 1978, February 1979 and March 1985 - i.e. before the diversion of the sewage - were similar to those found during the same months in other years (Tab. 2). In August 1978, however, the concentration of ammonium nitrogen was lower than was found during the same month in the following years.

Higher concentrations of total phosphorus were always found at the end of stratification, particularly affecting the hypolimnic waters (Fig. 2). In 1988-1989, the annual mean $\left(386 \mathrm{mg} \mathrm{P} \mathrm{m}^{-3}\right)$ was highest, and was nearly as high in 1996-1997 (305 $\left.\mathrm{mg} \mathrm{P} \mathrm{m}^{-3}\right)$; in 1994, its value was lower $\left(167 \mathrm{mg} \mathrm{P} \mathrm{m}^{-3}\right)$, about $50 \%$ of the values of the other two years (Tab. 3). In February 1979 and March 1985, total phosphorus values fell within the range of parameter variation during the same period in the following years, whereas in August 1978, in stratification conditions, the concentration was lower (Tab. 2).

In 1997, the annual mean and the peak of chlorophyll- $a$ were lower than those of previous years (Tabs 2 and 3). The highest concentrations (Fig. 3) were always found in the top $5 \mathrm{~m}$ and occurred during the summer months (between July and September). The highest value was found in August 1978; the value of $100 \mathrm{mg}$ $\mathrm{m}^{-3}$ was never exceeded. 
Tab. 2. Monthly mean values on the water column of some parameters during the different periods of study on Lake Bidighinzu.

\begin{tabular}{|c|c|c|c|c|c|c|c|c|c|c|c|c|}
\hline & Jan & Feb & Mar & Apr & May & Jun & Jul & Aug & Set & Oct & Nov & Dic \\
\hline \multicolumn{13}{|c|}{ Temperature $\left({ }^{\circ} \mathrm{C}\right)$} \\
\hline 1978 & - & - & - & - & - & - & - & 23.3 & - & - & - & - \\
\hline 1979 & - & 9.7 & - & - & - & - & - & - & - & - & - & - \\
\hline 1985 & - & - & - & - & - & - & - & - & - & - & - & - \\
\hline 1988 & - & - & 8.5 & 11.0 & 16.4 & 18.2 & 22.8 & 23.2 & 20.0 & - & 15.0 & 9.0 \\
\hline 1989 & - & - & 11.2 & 13.4 & - & - & - & - & - & - & - & - \\
\hline 1994 & - & - & 10.2 & - & - & 20.8 & - & - & 20.5 & - & - & 12.0 \\
\hline 1996 & - & - & - & - & - & - & - & - & - & - & - & 11.2 \\
\hline 1997 & 9.1 & 9.8 & 11.9 & 14.6 & 16.7 & 20.0 & 19.8 & 22.4 & 18.6 & 15.4 & 12.0 & - \\
\hline \multicolumn{13}{|c|}{ Ammonium nitrogen $\left(\mathrm{mg} \mathrm{N} \mathrm{m}^{-3}\right)$} \\
\hline 1978 & - & - & - & - & - & - & - & 75 & - & - & - & - \\
\hline 1979 & - & 140 & - & - & - & - & - & - & - & - & - & - \\
\hline 1985 & - & - & 79 & - & - & - & - & - & - & - & - & - \\
\hline 1988 & - & - & 119 & 74 & 456 & 873 & 571 & 350 & 536 & - & 468 & 757 \\
\hline 1989 & - & - & 850 & 636 & - & - & - & - & - & - & - & - \\
\hline 1994 & - & - & 112 & - & - & 15 & - & - & 159 & - & - & 565 \\
\hline 1996 & - & - & - & - & - & - & - & - & - & - & - & 768 \\
\hline 1997 & 680 & 463 & 97 & 237 & 246 & 342 & 525 & 521 & 429 & 779 & 910 & - \\
\hline \multicolumn{13}{|c|}{ Nitrate nitrogen $\left(\mathrm{mg} \mathrm{N} \mathrm{m}^{-3}\right)$} \\
\hline 1978 & - & - & - & - & - & - & - & 56 & - & - & - & - \\
\hline 1979 & - & 649 & - & - & - & - & - & - & - & - & - & - \\
\hline 1985 & - & - & 641 & - & - & - & - & - & - & - & - & - \\
\hline 1988 & - & - & 707 & 518 & 57 & 29 & 27 & 28 & 74 & - & 270 & 474 \\
\hline 1989 & - & - & 765 & 471 & - & - & - & - & - & - & - & - \\
\hline 1994 & - & - & 537 & - & - & 23 & - & - & 24 & - & - & 1449 \\
\hline 1996 & - & - & - & - & - & - & - & - & - & - & - & 538 \\
\hline 1997 & 649 & 827 & 917 & 499 & 408 & 30 & 35 & 38 & 103 & 90 & 852 & - \\
\hline \multicolumn{13}{|c|}{ Total phosphorus $\left(\mathrm{mg} \mathrm{P} \mathrm{m}^{-3}\right.$ ) } \\
\hline 1978 & - & - & - & - & - & - & - & 143 & - & - & - & - \\
\hline 1979 & - & 162 & - & - & - & - & - & - & - & - & - & - \\
\hline 1985 & - & - & 266 & - & - & - & - & - & - & - & - & - \\
\hline 1988 & - & - & 255 & 256 & 423 & 540 & 571 & 531 & 531 & - & 309 & 201 \\
\hline 1989 & - & - & 346 & 284 & - & - & - & - & - & - & - & - \\
\hline 1994 & - & - & 163 & - & - & 92 & - & - & 193 & - & - & 214 \\
\hline 1996 & - & - & - & - & - & - & - & - & - & - & - & 283 \\
\hline 1997 & 278 & 269 & 193 & 195 & 216 & 303 & 407 & 368 & 580 & 296 & 271 & - \\
\hline \multicolumn{13}{|c|}{ Hypolimnic oxygen $(\%)$} \\
\hline 1978 & - & - & - & - & - & - & - & $<10$ & - & - & - & - \\
\hline 1979 & - & 80 & - & - & - & - & - & - & - & - & - & - \\
\hline 1985 & - & - & - & - & - & - & - & - & - & - & - & - \\
\hline 1988 & - & - & 66 & 72 & $<10$ & $<10$ & $<10$ & $<10$ & 10 & - & 22 & 52 \\
\hline 1989 & - & - & 17 & 28 & - & - & - & - & - & - & - & - \\
\hline 1994 & - & - & 45 & - & - & 47 & - & - & $<10$ & - & - & 33 \\
\hline 1996 & - & - & - & - & - & - & - & - & - & - & - & 72 \\
\hline 1997 & 42 & 68 & 51 & 65 & 31 & 22 & 12 & $<10$ & $<10$ & 64 & 51 & - \\
\hline \multicolumn{13}{|c|}{ Chlorophyll- $a\left(\mathrm{mg} \mathrm{m}^{-3}\right)$} \\
\hline 1978 & - & - & - & - & - & - & - & 112 & - & - & - & - \\
\hline 1979 & - & 9 & - & - & - & - & - & - & - & - & - & - \\
\hline 1985 & - & - & - & - & - & - & - & - & - & - & - & - \\
\hline 1988 & - & - & 10 & 26 & 6 & 24 & 57 & 29 & 12 & - & 10 & 4 \\
\hline 1989 & - & - & 1 & 9 & - & - & - & - & - & - & - & - \\
\hline 1994 & - & - & 29 & - & - & 6 & - & - & 75 & - & - & 16 \\
\hline 1996 & - & - & - & - & - & - & - & - & - & - & - & 5 \\
\hline 1997 & 1 & 3 & 8 & 3 & 4 & 13 & 11 & 41 & 11 & 11 & 12 & - \\
\hline \multicolumn{13}{|c|}{ Total phytoplankton biomass $\left(\mathrm{mg} \mathrm{l}^{-1}\right)$} \\
\hline 1978 & - & - & - & - & - & - & - & 133.0 & - & - & - & - \\
\hline 1979 & - & 9.3 & - & - & - & - & - & - & - & - & - & - \\
\hline 1985 & - & - & - & - & - & - & - & - & - & - & - & - \\
\hline 1988 & - & - & 1.1 & 1.7 & 2.9 & 8.6 & 12.2 & 4.4 & 3.2 & - & 3.7 & 0.5 \\
\hline 1989 & - & - & 0.9 & 6.1 & - & - & - & - & - & - & - & - \\
\hline 1994 & - & - & 21.6 & - & - & 14.5 & - & - & 23.4 & - & - & 10.4 \\
\hline 1996 & - & - & - & - & - & - & - & - & - & - & - & 0.9 \\
\hline 1997 & 0.2 & 1.6 & 4.4 & 1,0 & 1.3 & 9.6 & 3.8 & 11.3 & 5.4 & 5.6 & 10.4 & - \\
\hline
\end{tabular}



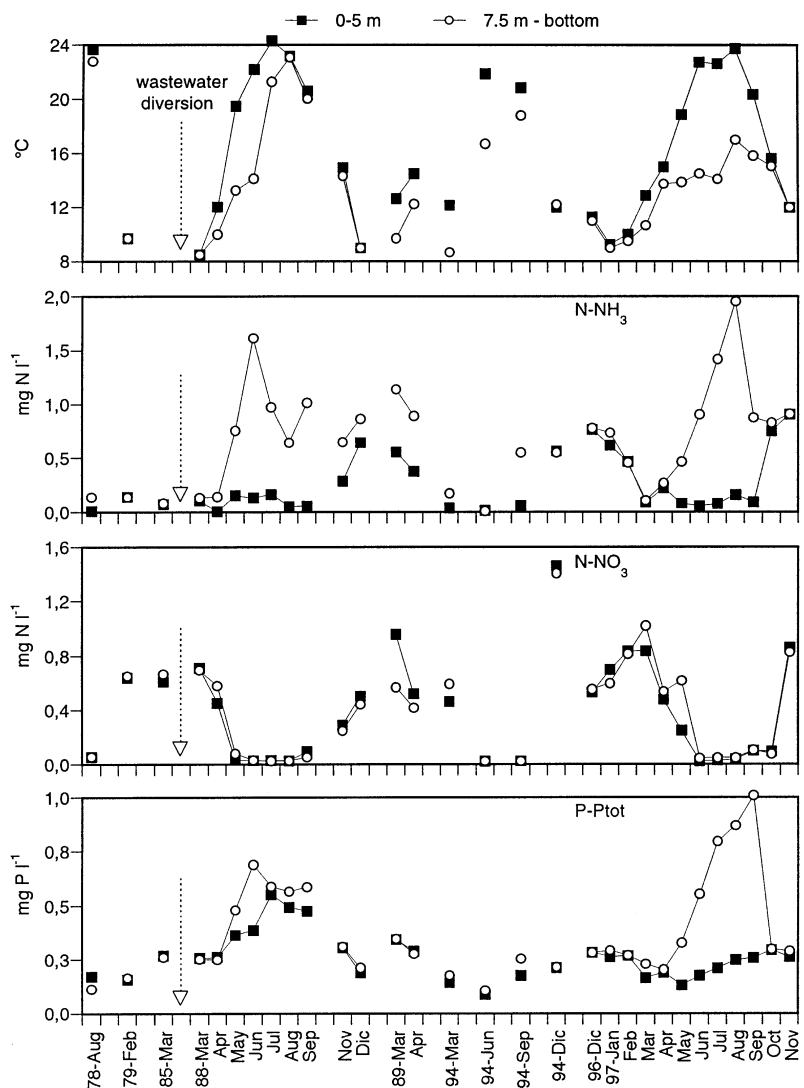

Fig. 2. Dynamics of temperature, ammonium nitrogen, nitrate nitrogen and total phosphorus in Lake Bidighinzu.

Tab. 3. Annual mean values on the water column of some parameters during the different periods of study on Lake Bidighinzu.

\begin{tabular}{lcccc}
\hline & & $1988-1989$ & 1994 & $1996-1997$ \\
\hline Ammonium nitrogen & $\left(\mathrm{mg} \mathrm{N} \mathrm{m}^{-3}\right)$ & 517 & 189 & 500 \\
Nitrate nitrogen & $\left(\mathrm{mg} \mathrm{N} \mathrm{m}^{-3}\right)$ & 311 & 539 & 415 \\
Inorganic nitrogen & $\left(\mathrm{mg} \mathrm{N} \mathrm{m}^{-3}\right)$ & 828 & 728 & 915 \\
Total phosphorus & $\left(\mathrm{mg} \mathrm{P} \mathrm{m}^{-3}\right)$ & 386 & 167 & 305 \\
Chlorophyll- $a$ & $\left(\mathrm{mg} \mathrm{m}^{-3}\right)$ & 17 & 33 & 11 \\
Total phytopl. biomass & $\left(\mathrm{mg} \mathrm{l}^{-1}\right)$ & 3.7 & 17.7 & 4.6 \\
\hline
\end{tabular}

The high concentration of chlorophyll- $a$ in August 1978 was due to an exceptional bloom of Ceratium hirundinella (O.F. Müller) Schrank, belonging to the Dinophyceae. This species was also the cause of the maximum biomass values (Fig. 3, Tab. 4). When chlorophyll- $a$ and biomass values were highest, the dominant classes were Cyanophyceae in 1988-1989 with $M i$ crocystis aeruginosa Kg., Microcystis flos-aquae (Wittr.) Kichn., Anabaena flos-aquae (Lyngb.) Bréb., Aphanizomenon flos-aquae (L.), Bacillariophyceae and Dinophyceae in 1994 with Stephanodiscus sp. and C. hirundinella, respectively, and Bacillariophyceae in 1996-1997 with Cyclotella spp. In February 1979, Conjugatophyceae with Closterium spp. was the most abundant class. Summer increases of Cyanophyceae and more or less copious and sudden developments of Chlorophyceae were observed in every year of the study, especially between May and June. Increases of Dinophyceae were observed mostly in summer and autumn.

\section{DISCUSSION AND CONCLUSIONS}

Over the years, Lake Bidighinzu has been subjected to a number of interventions in an attempt to solve its problems of eutrophication.

Chronologically, the first of these, which are still in use, are the aeration system - often modified (Fig. 1) against hypolimnic anoxia, and the microfiltering phase in the potabilization plant against the copious algal presence (above all Microcystis, Anabaena and Aphanizomenon, belonging to the Cyanophyceae). However, these solutions merely treat the symptoms of certain critical phases.

As already pointed out (Lugliè \& Sechi 1993), the aeration system operates mainly during the summerautumn period, when the lake stratifies. The system involves injecting air directly into the deep hypolimnion (1 meter from the bottom), which causes some changes in the lake's thermal state and the break-up of the stratification. This allows hypolimnic nutrients to spread into the photic zone, increasing the development of phytoplankton. 
Tab. 4. Monthly mean values of phytoplankton biomass $\left(\mathrm{mg}^{-1}\right)$ during the different periods of study on Lake Bidighinzu.

\begin{tabular}{|c|c|c|c|c|c|c|c|c|c|c|c|c|}
\hline & Jan & Feb & Mar & Apr & May & Jun & Jul & Aug & Set & Oct & Nov & Dic \\
\hline \multicolumn{13}{|c|}{ Cyanophyceae } \\
\hline 1978 & - & - & - & - & - & - & - & 1.20 & - & - & - & - \\
\hline 1979 & - & + & - & - & - & - & - & - & - & - & - & - \\
\hline 1988 & - & - & 0 & 0.17 & 0.17 & 9.70 & 13.10 & 5 & 5.49 & - & 5.19 & 0.40 \\
\hline 1989 & - & - & 0 & 11.1 & - & - & - & - & - & - & - & - \\
\hline 1994 & - & - & 0.10 & - & - & 0.33 & - & - & 0.38 & - & - & 0 \\
\hline 1996 & - & - & - & - & - & - & - & - & - & - & - & 0 \\
\hline 1997 & 0 & 0 & 0 & 0.47 & 0.07 & 1.12 & 0.27 & 2.12 & 0.32 & 0.04 & 0.02 & - \\
\hline \multicolumn{13}{|c|}{ Chlorophyceae } \\
\hline $1978^{\circ}$ & - & - & - & - & - & - & - & 0 & - & - & - & - \\
\hline 1979 & - & 0 & - & - & - & - & - & - & - & - & - & - \\
\hline 1988 & - & - & 0 & 0 & 5.25 & 1.43 & 0 & 0 & 0 & - & 0.01 & 0 \\
\hline 1989 & - & - & 0.46 & 0.02 & - & - & - & - & - & - & - & - \\
\hline 1994 & - & - & 0.38 & - & - & 13.8 & - & - & 0.37 & - & - & 0.48 \\
\hline 1996 & - & - & - & - & - & - & - & - & - & - & - & 0.05 \\
\hline 1997 & 0.04 & 0.13 & 0.04 & 0.34 & 0.71 & 2.69 & 1.36 & 1.38 & 0.31 & 0.47 & 0.08 & - \\
\hline \multicolumn{13}{|c|}{ Bacillariophyceae } \\
\hline 1978 & - & - & - & - & - & - & - & 0.10 & - & - & - & - \\
\hline 1979 & - & + & - & - & - & - & - & - & - & - & - & - \\
\hline 1988 & - & - & 0.88 & 0.74 & 0.02 & 0.89 & 0 & 0 & 0.01 & - & 0.01 & 0.03 \\
\hline 1989 & - & - & 0 & 0 & - & - & - & - & - & - & - & - \\
\hline 1994 & - & - & 20.1 & - & - & 0.11 & - & - & 0.52 & - & - & 7.73 \\
\hline 1996 & - & - & - & - & - & - & - & - & - & - & - & 0.23 \\
\hline 1997 & 0.14 & 1.34 & 4.28 & 0.16 & 0.5 & 4.87 & 0.96 & 6.17 & 2.75 & 4.09 & 10.10 & - \\
\hline \multicolumn{13}{|c|}{ Dinophyceae } \\
\hline $1978^{\circ}$ & - & - & - & - & - & - & - & 131 & - & - & - & - \\
\hline 1979 & - & 0 & - & - & - & - & - & - & - & - & - & - \\
\hline 1988 & - & - & 0 & 0 & 0 & 0 & 0 & 0 & 0 & - & 0 & 0 \\
\hline 1989 & - & - & 0 & 0 & - & - & - & - & - & - & - & - \\
\hline 1994 & - & - & 0 & - & - & 0.06 & - & - & 21.2 & - & - & 0 \\
\hline 1996 & - & - & - & - & - & - & - & - & - & - & - & 0 \\
\hline 1997 & 0 & 0 & 0 & 0 & 0.02 & 0.86 & 1.18 & 1.08 & 1.90 & 0.96 & 0 & - \\
\hline \multicolumn{13}{|c|}{ Euglenophyceae } \\
\hline 1978 & - & - & - & - & - & - & - & 0 & - & - & - & - \\
\hline 1979 & - & 0 & - & - & - & - & - & - & - & - & - & - \\
\hline 1988 & - & - & 0 & 0 & 0 & 0.12 & 0 & 0 & 0 & - & 0.01 & 0 \\
\hline 1989 & - & - & 0 & 0 & - & - & - & - & - & - & - & - \\
\hline 1994 & - & - & 0 & - & - & 0.12 & - & - & 0 & - & - & 0.01 \\
\hline 1996 & - & - & - & - & - & - & - & - & - & - & - & 0 \\
\hline 1997 & 0 & 0.01 & 0.01 & 0 & 0 & 0 & 0 & 0.01 & 0.02 & 0.01 & 0 & - \\
\hline \multicolumn{13}{|c|}{ Conjugatophyceae } \\
\hline 1978 & - & - & - & - & - & - & - & 0.70 & - & - & - & - \\
\hline 1979 & - & 9.30 & - & - & - & - & - & - & - & - & - & - \\
\hline 1988 & - & - & 0 & 0 & 0 & 0 & 0 & 0 & 0 & - & 0 & 0 \\
\hline 1989 & - & - & 0 & 0 & - & - & - & - & - & - & - & - \\
\hline 1994 & - & - & 0.01 & - & - & 0.04 & - & - & 0.76 & - & - & 0.91 \\
\hline 1996 & - & - & - & - & - & - & - & - & - & - & - & 0.04 \\
\hline 1997 & 0.06 & 0.05 & 0.01 & 0 & 0 & 0.04 & 0.04 & 0.24 & 0.07 & 0.05 & 0.13 & - \\
\hline \multicolumn{13}{|c|}{ Cryptophyceae } \\
\hline 1978 & - & - & - & - & - & - & - & 0 & - & - & - & - \\
\hline 1979 & - & 0 & - & - & - & - & - & - & - & - & - & - \\
\hline 1988 & - & - & 0.43 & 0.97 & 0.02 & 0 & 0 & 0 & 0 & - & 0.02 & 0.06 \\
\hline 1989 & - & - & 0 & 0 & - & - & - & - & - & - & - & - \\
\hline 1994 & - & - & 1.03 & - & - & 0.01 & - & - & 0.11 & - & - & 1.27 \\
\hline 1996 & - & - & - & - & - & - & - & - & - & - & - & 0.56 \\
\hline 1997 & 0 & 0.10 & 0.04 & 0.02 & 0.01 & 0.03 & 0.02 & 0.32 & 0.06 & 0.02 & 0 & - \\
\hline \multicolumn{13}{|l|}{ Other } \\
\hline 1978 & - & - & - & - & - & - & - & 0 & - & - & - & - \\
\hline 1979 & - & 0 & - & - & - & - & - & - & - & - & - & - \\
\hline 1988 & - & - & 0 & 0 & 0 & 0 & 0 & 0 & 0 & - & 0 & 0 \\
\hline 1989 & - & - & 0 & 0 & - & - & - & - & - & - & - & - \\
\hline 1994 & - & - & 0 & - & - & 0 & - & - & 0 & - & - & 0 \\
\hline 1996 & - & - & - & - & - & - & - & - & - & - & - & 0.02 \\
\hline 1997 & 0.06 & 0.06 & 0.02 & 0 & 0 & 0.04 & 0.04 & 0.21 & 0.09 & 0.06 & 0.13 & - \\
\hline
\end{tabular}



Dinophyceae
Chlorophyceae $\quad \boxminus$ Cryptophyceae
- $0-5 \mathrm{~m}$
Conjugatophyceae
Cyanophyceae
$\$$ Bacillariophyceae
- $7.5 \mathrm{~m}$ - bottom
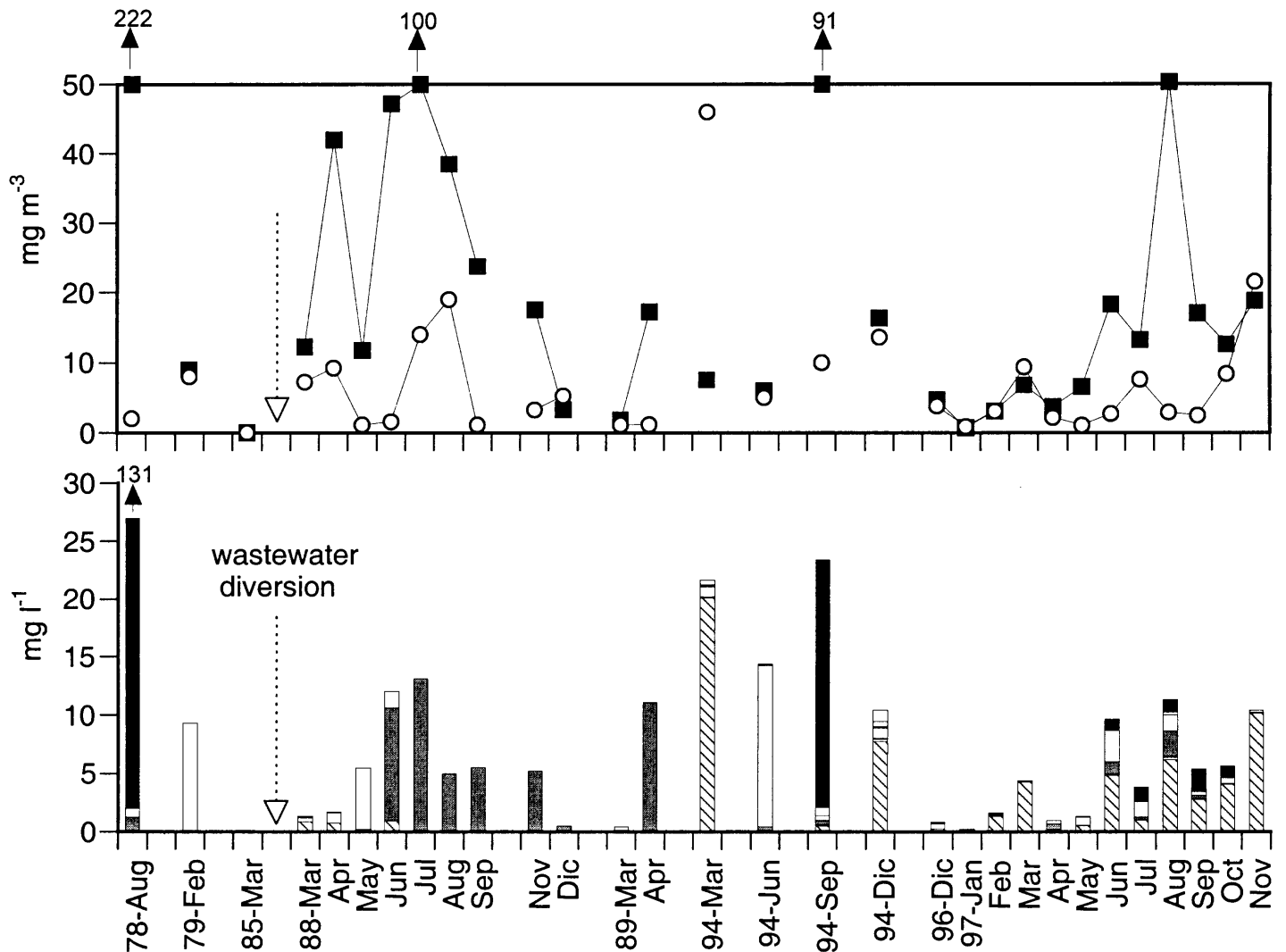

Fig. 3. Dynamics of chlorophyll- $a$ and class composition of phytoplanktonic biomass in Lake Bidighinzu.
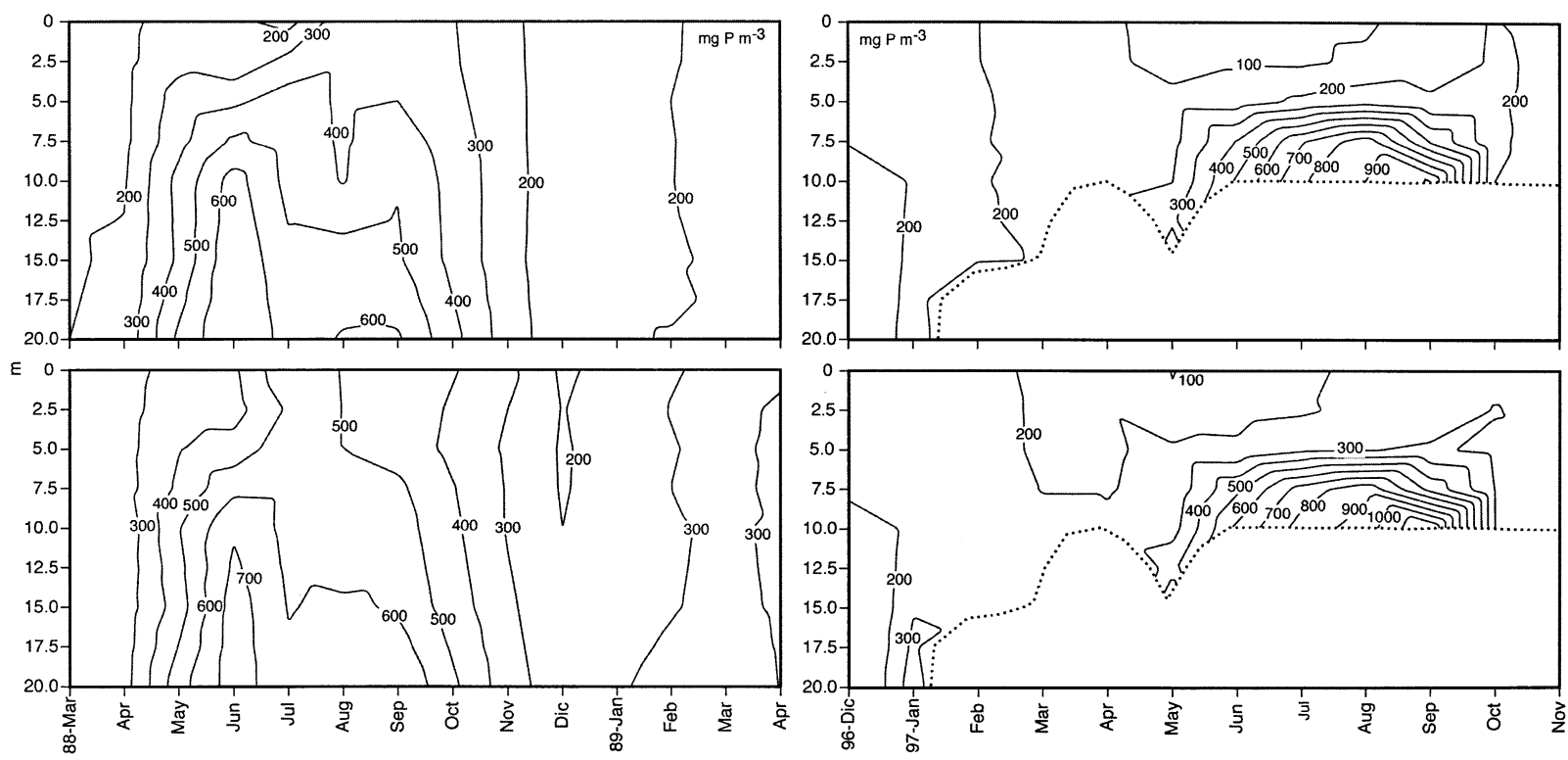

Fig. 4. Distribution of reactive (above) and total phosphorus (below) in Lake Bidighinzu during 1988-1989 and 1996-1997. Dashed line shows depth variation as a result of lake volume variation. 
Consequently, on the one hand the injection of air into the hypolimnic waters temporarily remedies the deoxygenated state of water destined for potabilization, but on the other hand it determines a higher availability of nutrients for phytoplankton, which is found at every depth because of the induced thermic homogeneity. The algal microfiltering system was not always able to solve this problem, particularly during the blooms of Cyanophyceae (Sechi 1992).

After an assessment of the point sources (Sechi 1989), a water pipe was built to divert downstream the urban and industrial wastes of Thiesi. On the basis of theoretic estimations and experimental verifications, it was thought that the trophic level of the lake would decrease if the Vollenweider model was used (O.E.C.D. 1980), because the status of the lake fell within the series of cases provided for by this model. Owing to an increase in industrial activities, especially in the sector of butter and cheese production, the current load should correspond to the value reported in table 5 .

Tab. 5. Theoretic P-loads of Lake Bidighinzu.

\begin{tabular}{lc}
\hline & $\mathrm{t} \mathrm{y}^{-1}$ \\
\hline Urban wastes & 1.8 \\
Industrial wastes & 9.0 \\
Uncultivated land & 0.8 \\
Fertilized land & 0.1 \\
Cattle breeding & 0.1 \\
Total load & 11.8 \\
\hline
\end{tabular}

All the more reason, considering the nearly redoubled load of phosphorus, to expect that the diversion would produce a considerable improvement. However, while the Vollenweider model (O.E.C.D. 1980) indicates the likely effects, it is not so easy to predict just when they will be achieved. In fact, the time required depends on the lake's morphometric characteristics, the phosphorus release from the sediment, the interannual variability of nutrient availability in the water and the consequent biological reaction of phytoplankton development, which is not always directly in relation with the external load.

With reference to Sas (1989), the effects of lake restoration after external load reduction can be assessed by considering two subsystems. The first (Subsystem 1) is in relation with the phosphorus concentration in the lake as regards the inflow load and the second (Subsystem 2) is in relation with the phytoplankton reaction as chlorophyll- $a$ and biomass as regards the phosphorus concentrations in the lake.

The data collected in 1994 are not considered (as annual averages) in comparing the values of Lake Bidighinzu: as they refer to only four seasonal samplings, they are not representative enough of the conditions that characterised the lake in that year.

Subsystem 1: the high phosphorus concentrations still present in the lake water in 1996-1997 might be conceded as possible during the first cycle of study (1988-1989), following the year when the by-pass became operational, but they are less admissible after ten years. As a matter of fact, though Lake Bidighinzu may be regarded as a shallow lake strongly affected by the phosphorus release from the sediment, by 1996-1997 the phosphorus concentrations in the lake should have changed compared with previous years. In fact, it takes about five years for the release from the sediment to become insignificant (Sas 1989). However, a comparison of the phosphorus and nitrogen concentrations found in samples taken in the same periods before and after the diversion shows no major reduction or decreasing trend. The distribution of reactive and total phosphorus (Fig. 4) shows that higher concentrations are reached during the summer in the zone close to the sediment, which may signify a clean release. However, in this case, phosphorus concentrations in the lake water should also have decreased. On the contrary, reactive phosphorus was always more than $50 \%$ of total phosphorus in both 1988-1989 and 1996-1997, while concentrations were always above $10 \mathrm{mg} \mathrm{P} \mathrm{m}^{-3}$. These values prove that phosphorus as reducing factor of phytoplankton development is an aim that was not achieved after the diversion.

Subsystem 2: annual mean values of chlorophyll- $a$ and total biomass also continued to be typical of eutrophic environments after the diversion, with a slight fall, hardly constituting an improvement, in chlorophyll- $a$ in 1996-1997, compared to the values recorded in 19881989. The highest values, recorded in August 1978 (112 $\mathrm{mg} \mathrm{m}^{-3}$ and $133 \mathrm{mg} \mathrm{m}^{-3}$, respectively) due to a bloom of C. hirundinella, were never repeated, and annual peaks were always lower than $100 \mathrm{mg} \mathrm{m}^{-3}$ and $25 \mathrm{mg} \mathrm{m}^{-3}$ in subsequent checks. During the last year, phytoplankton composition was characterised by Bacillariophyceae, though in the summer there was a considerable presence of Cyanophyceae (which were the dominant class in 1978-1979). These variations are difficult to explain and it is not certain that they are a sign of a biological reaction to the diversion of the wastes, especially since at the same time no variations in nutrient availability were recorded in the water column. In fact, values found during different periods and with differences in phytoplankton composition are those of a highly eutrophic lake, and may be related to the interannual variability of phytoplankton in Sardinian lakes (Sechi \& Lugliè 1996). Besides, the possible nutrient availability in the photic zone, which is linked to the operation of the aeration system, might be considerable and could vary according to the time and the duration of its use.

Table 6 shows both the phosphorus and chlorophyll$a$ values that were expected after the diversion, and those that were actually found, which indicate that there was no improvement in the quality of the water. Phosphorus concentrations found in the lake are very close to those obtained through calculation, assuming an exter- 
Tab. 6. Theoretic and experimental values of phosphorus and chlorophyll- $a$ in Lake Bidighinzu.

\begin{tabular}{lcc}
\hline Theoretic P-load with diversion (A) & $\left(\mathrm{t} \mathrm{y}^{-1}\right)$ & 1 \\
Theoretic P-load without diversion (B) & $\left(\mathrm{t} \mathrm{y}^{-1}\right)$ & 11.8 \\
Theoretic lake P-concentration from A & $\left(\mathrm{mg} \mathrm{P} \mathrm{m}^{-3}\right)$ & 22 \\
Theoretic lake P-concentration from B & $\left(\mathrm{mg} \mathrm{P} \mathrm{m}^{-3}\right)$ & 320 \\
Experimental lake P-concentration in 1988-1989 & $\left(\mathrm{mg} \mathrm{P} \mathrm{m}^{-3}\right)$ & 386 \\
Experimental lake P-concentration in 1996-1997 & $\left(\mathrm{mg} \mathrm{P} \mathrm{m}^{-3}\right)$ & 305 \\
Theoretic chlorophyll- $a$ from A & $\left(\mathrm{mg} \mathrm{m}^{-3}\right)$ & 7 \\
Theoretic chlorophyll- $a$ from B & $\left(\mathrm{mg} \mathrm{m}^{-3}\right)$ & 33 \\
Experimental chlorophyll- $a$ in 1988-1989 & $\left(\mathrm{mg} \mathrm{m}^{-3}\right)$ & 17 \\
Experimental chlorophyll- $a$ in 1996-1997 & $\left(\mathrm{mg} \mathrm{m}^{-3}\right)$ & 11 \\
\hline
\end{tabular}

nal phosphorus load of $11.8 \mathrm{t} \mathrm{y}^{-1}$. On the other hand, the values of chlorophyll- $a$ are lower than those expected. Situations in which the expected and the measured values did not coincide were also found in Lake Sos Canales (Lugliè et al. 1996), where the experimental values of chlorophyll- $a$ were higher than the theoretic ones. This confirms that phytoplanktonic developments depend on several other variables besides the availability of phosphorus in waters, and in man-made lakes characterised by a very high interannual variability of environmental conditions, the behaviour of phytoplankton is subject to a wider margin of uncertainty (Alvarez Cobelas et al. 1994). For example, N/P ratio in L. Bidighinzu was always very low, confirming its high eutrophic state and underlining the importance of nitrogen on the development and composition of phytoplankton.

The failure of the attempt to recover Lake Bidighinzu can be explained in several ways. Without any assessment of the possible release of phosphorus from the sediment, or experimental assessments of the inflow loads to the lake, the data available indicate as the most likely explanation the non-use, or only partial use, of the by-pass. This may have kept unchanged or only partially modified the quantity of nutrients flowing into the lake.

\section{REFERENCES}

Alamanni, U., G. Bo \& A. Maida. 1968. Influenza della microfiltrazione sulla potabilizzazione dell'acqua del bacino artificiale del Bidighinzu (Sassari). Boll. Lab. Chim. Prov., 19: 742 .

Alamanni, U., G. Bo, F. Dragone, A. Maida, S. Pettinato \& E. Muresu. 1971. Il lago artificale del Bidighinzu (Sassari) quale riserva d'acqua ad uso potabile: indagini ed osservazioni nei primi sei anni del suo funzionamento. Rivista Italiana d'Igiene, 31: 79 .

Alvarez Cobelas, M. \& M. Arauzo. 1994. Phytoplankton responses of varying time scales in a eutrophic reservoir. Arch. Hydrobiol. Beih. Ergebn. Limnol., 40: 69-80.

Fresenius, W.K.E., W.W. Quentin \& W. Scheneider. 1988. Water analysis. A practical guide to physico-chemical and microbiological water examination and quality assurance. Springer-Verlag, Berlin: 320 pp.

Findenegg, I. 1974. Expressions of populations. In: R. Vollenweider (Ed.), A manual of methods for measuring pri- mary production in aquatic environments. I.B.P. 12. Blackwell Scientific Publications, Oxford: 16-18.

Goltermann, H.L., R.S. Clymo \& M.A.M. Ohnstad. 1978 Method for physical and chemical analysis of fresh waters. I.B.P. 8. Blackwell Scientific Publications, Oxford: $214 \mathrm{pp}$.

Lugliè, A. \& N. Sechi. 1993. Trophic status and phytoplankton in Lake Bidighinzu. Giorn. Bot. Ital., 127: 765-785.

Lugliè, A., G. Mameli \& N. Sechi. 1996. Indagine limnologica pluriennale (dal 1991 al 1993) sul lago artificiale di Sos Canales (Sardegna Settentrionale). In: G. Albertelli, A. De Maio \& M. Piccazzo (Eds), Atti dell'11 ${ }^{\circ}$ Congresso A.I.O.L. - Sorrento, 26-28 Ottobre 1994: 479-489.

Marchetti R., R. Barone, S. Calvo, A. Lugliè, L. Naselli Flores \& N. Sechi. 1992. Studies on Italian reservoirs. In: P. Guilizzoni, G. Tartari \& G. Giussani (Eds). Limnology in Italy. Mem. Ist. ital. Idrobiol., 50: 337-363.

Messina, U. 1966. Attivazione di moti convettivi nelle acque di un lago per promuovere le autodepurazioni. Ingegneria Sanitaria, 282: 4-14.

O.E.C.D. 1980. Regional project shallow lakes and reservoirs. Final report of cooperative programme for monitoring of inland waters (eutrophication control). Organization for Cooperation and Development, Paris: 154 pp.

Provini, A., R. Mosello, M. Pettine, A. Puddu, E. Rolle \& F.M. Spaziani. 1979. Metodi e problemi per la valutazione dei carichi dei nutrienti. Atti Conv. L'eutrofizzazione in Italia, Roma 1978: 121-158.

Sas, H. 1989. Lake restoration by reduction of nutrient loading: expectations, experiences, extrapolations. Academia Verlag Richarz, Sankt Augustin: 497 pp.

Sechi, N. \& A. Cossu. 1979. Prime valutazioni sui livelli trofici di alcuni bacini artificiali della Sardegna. Mem. Ist. ital. Idrobiol., 37: 259-276.

Sechi, N. 1983. Il fitoplancton e lo stato trofico di alcuni laghi artificiali della Sardegna. In: R. Frache \& F. de Strobel (Eds), Atti $4^{\circ}$ Congresso A.I.O.L. - Chiavari, 1-3 Dicembre 1980, (24): 1-12.

Sechi, N. 1986. Il problema dell'eutrofizzazione dei laghi. La situazione trofica degli invasi della Sardegna. Boll. Soc. Sarda Sci. Nat., 25: 49-62.

Sechi, N. 1989. L'eutrofizzazione dei laghi artificiali della Sardegna. In: Provincia di Cagliari (Ed.), Qualità dell'acqua in Sardegna. Provincia di Cagliari, Cagliari: 71-82.

Sechi, N. 1992. Le problematiche legate al fitoplancton nelle acque lacustri destinate ad uso potabile. Giorn. Bot. Ital., 126: 237-251.

Sechi, N. \& A. Lugliè. 1996. Phytoplankton in Sardinian reservoirs. Giorn. Bot. Ital., 130: 977-994.

Strickland, J.D.H. \& T.R. Parsons. 1968. A practical handbook seewater analysis. Bull. Fish. Res. Board Can., 167, Ottawa: 310 pp. 